\section{Caregivers utilisation of zinc plus oral rehydration solution for home management of childhood diarrhoea in rural and urban communities of Kano, Nigeria}

\author{
Ibrahim Rabiu Jalo, ${ }^{1}$ \\ Gajida Auwal Umar, ${ }^{1}$ \\ Jibo Abubakar Mohammed, ${ }^{1}$ \\ Ibrahim Usman Muhammad, ${ }^{2}$ \\ Abulfathi Aisha Aliyu, ${ }^{2}$ \\ Abubakar Isa Sadeeq ${ }^{1}$ \\ ${ }^{1}$ Department of Community Medicine, \\ Bayero University/Aminu Kano \\ Teaching Hospital, Kano; ${ }^{2}$ Department \\ of Community Medicine, Aminu Kano \\ Teaching Hospital, Kano, Nigeria
}

\begin{abstract}
Diarrhea remains a major cause of morbidity and mortality globally, and still poses a significant threat to the health, wellbeing and survival of under-fives in many developing countries, especially in Africa. This is despite the existence of simple, effective treatment - zinc plus ORS. A comparative cross- sectional design was used to collect information from 302 caregivers. Data was analysed using SPSS version 20. Utilization of zinc plus ORS by caregivers was found to be good $(73.5 \%)$ in both settings; up to 120 $(78.9 \%)$ of the caregivers in the urban community compared to over two-thirds 102 $(68.0 \%)$ of those in the rural community had used zinc plus ORS. This difference was statistically significant between urban and rural caregivers $(\mathrm{P}=0.01)$. Caregivers having poor knowledge of zinc plus ORS were $98 \%$ less likely to use zinc plus ORS $(\mathrm{P}=0.00$, $\mathrm{AOR}=0.02,95 \% \mathrm{CI}=0.00-0.12$ ), caregivers whose children had non severe diarrhoea are $80 \%$ less likely to use zinc plus ORS $(\mathrm{P}=0.00, \quad \mathrm{AOR}=0.20,95 \% \quad \mathrm{CI}=0.09-0.47)$ and caregivers in urban areas are 1.5 times more likely to give zinc plus ORS for any episode of diarrhoea $(\mathrm{P}=0.01$. $\mathrm{AOR}=1.53$, $95 \% \mathrm{CI}=1.48-4.54)$. Utilisation of zinc plus ORS was fair in both rural and urban areas of Kano and continued efforts to reach caregivers using a variety of channels are needed to change caregiver's knowledge and utilization of zinc plus ORS and alter incorrect diarrhoea treatment practices.
\end{abstract}

\section{Introduction}

Diarrhoea is one of the leading causes of death among children under the ages of five years globally. It accounts for $9 \%$ of all under-five deaths: a loss of more than 531,000 child lives in 2015. ${ }^{1}$ Most of these deaths occur among children less than 2 years old. Diarrhoea remains a major cause of morbidity and mortality globally and still poses a significant threat to the health, wellbeing and survival of under five in many developing countries today, especially in Africa and South East Asia, and accounts for as much as $16 \%$ of childhood deaths. ${ }^{2}$ According to the 2013 Nigeria National Demographic and Health Survey (NDHS), 1 in 10 children under the age 5 years in Nigeria had diarrhoea, and 1 in 50 had diarrhoea with blood, in the two weeks prior to the survey. ${ }^{2}$ Today, many children with diarrhoea in low-income countries do not receive the recommended treatment, and trend data suggest that there has been little progress since $2000 .{ }^{3}$ Current evidence suggests that advances in managing diarrhoeal diseases, zinc supplementation for the treatment of diarrhoea has been shown to decrease the duration and severity of the diarrhoeal episode, diarrhoea hospitalization rates and, in some studies, all-cause mortality. 3,4 Diarrhoea has been defined as the passage of three (3) or more loose or watery stools per day, or more frequently than is normal for the individual..$^{5}$ It's usually a symptom of gastrointestinal pathology, caused by malnutrition and a variety of bacterial, viral and parasitic organisms. Infection is spread through contaminated food or drinking water, or from person to person as a result of poor hygiene. Severe diarrhoea leads to fluid loss, and may be life-threatening, particularly in young children and people who are malnourished or have impaired immunity. ${ }^{4}$ Other complications will include electrolyte imbalance, malnutrition, irritable bowel syndrome and death if untreated. Other important causes of diarrhoea include under-nutrition. ${ }^{6}$ Effective interventions that have been shown to reduce morbidity and mortality from diarrhoea in addition to prevention and treatment of dehydration with appropriate fluids include: breastfeeding, continued feeding and selective use of antibiotics. ${ }^{3,5}$ These interventions reduce the duration and severity of diarrhoeal episodes and lower their incidence. Because these are simple interventions that require minimal skills and can be successfully implemented at home, families and communities are key to achieving the goals, especially in lower income countries. $., 7,8$

The WHO and UNICEF issued joint statement recommending low-osmolarity oral rehydration salts (ORS) and zinc in management of childhood diarrhoea. Zinc
Correspondence: Rabiu Ibrahim Jalo, Department of Community Medicine, Bayero University/Aminu Kano Teaching Hospital, Kano, Nigeria.

E-mail: rabiuibrahimjalo@yahoo.com

Key words: Zinc, ORS, Urban, Rural, Kano.

Acknowledgments: The authors wish to acknowledge the technical assistance provided by Network for Behavioral Research for Child Survival in Nigeria (NETBRECSIN).

Contributions: IRJ, GAU, JAM and AIS participated in conception, design, and interpretation of data, drafting of manuscript and revising it critically for important intellectual content. KAA, AAA and UMI contributed in data collection and analysis.

Conflict of interest: the authors declare no potential conflict of interest.

Funding: none.

Received for publication: 5 November 2018 Revision received: 10 October 2019.

Accepted for publication: 10 October 2019.

This work is licensed under a Creative Commons Attribution NonCommercial 4.0 License (CC BY-NC 4.0).

(C) Copyright: the Author(s), 2019

Licensee PAGEPress, Italy

Pyramid Journal of Medicine 2019; 2:30

doi:10.4081/pjm.2019.30

supplementation reduces the severity, duration and recurrence of childhood acute diarrhoea. These beneficial effects of zinc in the treatment of diarrhoea led to the inclusion of a 10-14 days treatment regimen by the WHO/UNICEF ${ }^{5}$ but many children are still dying because these interventions are often not available or accessible where they are needed most. 5,6

Majority of diarrhoea related deaths occur at home, thus - caregivers utilisation of an effective intervention in the form of zinc plus ORS is extremely needed to significantly reduce these avoidable deaths. In addition to poor access to proper health care, most diarrhoeal episodes occur at home and may even end without necessarily any contact with the health care system. Information on the potential barriers and enablers to scaling up zinc plus ORS treatment for diarrhoea in northern Nigeria and especially Kano State is lacking.

Prevention and treatment of dehydration with appropriate fluids, breastfeeding, continued feeding and use of zinc plus ORS will reduce the duration and severity of diar- 
rhoeal episodes and lower their incidence. Families and communities are key to achieving the goals set for managing the disease by making the new recommendations routine practice in the home and health facility. With Kano State having $6.5 \%$ share of the national burden of diarrhoeal diseases among under- five children in Nigeria. ${ }^{2}$ Scaling up the use of zinc plus ORS can dramatically save the lives of these children. Baseline data is therefore needed with respect to utilisation and barriers to the use of zinc plus ORS by caregivers as well as on identifying enabling factors for use of zinc plus ORS among children under-five years of age. The study aimed to assess utilisation of zinc plus ORS and associated factors among caregivers of under fives. The study compared rural and urban areas because in subSaharan Africa, rural and urban populations differ demographically, in socio-economic and cultural composition, and in proximity to formal and informal treatment sources. Urban populations are generally younger, better educated, and more ethnically heterogeneous than rural populations. Also, government health services, private health facilities, pharmacies and drug shops selling over-the-counter medications are concentrated in urban areas.

\section{Materials and Methods \\ Study design}

A comparative cross- sectional design was used to assess caregiver's utilisation of zinc plus ORS in rural and urban communities of Kano, Nigeria. Kano is one of the 36 States of the Federal Republic of Nigeria and it lies between latitude $130 \mathrm{~N}$ in the North and $110 \mathrm{~N}$ in the South and longitude $80 \mathrm{~W}$ in the West and 100 in the East.

\section{Study population}

The study population comprised of caregivers of children within the ages of $0-$ 59 months who had diarrhoea in the three months prior to the survey.

\section{Sample size determination}

Sample size for the study was estimated using the formula for comparing two proportions, ${ }^{10}$ as stated below:

$$
\begin{gathered}
\mathrm{n}=\left(\mathrm{Z} \alpha+\mathrm{Z}_{1-\beta}\right)^{2}\left[\mathrm{Pl}(1-\mathrm{P} \mathrm{P})+\mathrm{P}_{2}\left(1-\mathrm{P}_{2}\right)\right] \\
\left(\mathrm{P}_{1}-\mathrm{P}_{2}\right)^{2}
\end{gathered}
$$

$\mathrm{n}=$ minimum sample size in each group

$\mathrm{Z} \alpha=$ Value of the standard normal deviate corresponding to the $\alpha$ level of significance at $95 \%$ (normal distribution table value = 1.96)
$\mathrm{Z}_{1-\beta}=$ Value of the standard normal deviate corresponding to the power of the test at $80 \%$ (normal distribution table value $=$ $0.84)$

$\mathrm{P}_{1}=$ Proportion of caregivers (in rural areas) who gave zinc plus ORS to children with diarrhoea (32). ${ }^{11}$

$\mathrm{P}_{2}=$ Proportion of caregivers (in urban area) who gave zinc plus ORS to children with diarrhoea (49.7). ${ }^{12}$

$\mathrm{P}_{1}-\mathrm{P}_{2}=$ Difference in proportion between children treated with zinc plus ORS.

$$
\begin{gathered}
\mathrm{n}=\overline{(1.96+0.84)^{2}\left[0.32(1-0.32)+0.49(1-0.51) /(0.32-0.49)^{2}\right.} \\
\mathrm{n}=2.630908 / 0.017424=140
\end{gathered}
$$

A ten percent (10\%) non-response rate was added. Hence, the sample size of 154 caregivers each in the urban and rural areas was obtained.

\section{Sampling technique}

A multistage sampling technique was used to select participants - LGA, Ward, Settlement, Household and Respondents.

\section{Study Instrument}

An interviewer - administered, pre-tested, semi-structured questionnaire adapted from previous studies, ${ }^{13,14}$ was used to collect data from eligible caregivers, after pretesting the questionnaire, it was adjusted to suit cultural appropriateness. Pre-testing also tested the ability of trained research assistants to administer the questionnaire.

\section{Data analysis}

Data collected were cleaned, entered and analysed using IBM SPSS version 20. Utilisation of zinc plus ORS was the dependent variable while the independent variables included caregiver's age, age of index child, respondents' sex, child's sex, place of residence, ethnicity, religion, marital status, place of residence, educational status, occupation, income, spouse's educational status, partner's occupation and number of living children. Chi-square test or Fisher's exact test was used where appropriate to analyse factors associated with caregiver's utilisation of zinc plus ORS. P value $<0.05$ was considered statistically significant. At multivariate level, all variables found to have $\mathrm{P}<0.05$ were entered into the binary logistic regression model to obtain adjusted odds ratio with $95 \%$ confidence intervals for predictors of utilisation of zinc plus ORS.

\section{Results}

\section{Socio-demographic characteristics}

\section{of respondents}

The mean ages $( \pm \mathrm{SD})$ of respondents in the urban and rural communities were $26.4 \pm 6.7$ and $24.8 \pm 5.4$ years respectively. About half $(51.9 \%)$ of the caregivers that participated in the study were in the age group 15-24 years. More than a third (38.7\%) of participating caregivers in the urban community were in the age group 25 34 years compared to a quarter $(27.6 \%)$ of those in the rural community. Most caregivers from both communities $98.0 \%$ urban versus $96.7 \%$ rural were Hausa and of the Islamic faith $95.3 \%$ versus $94.0 \%$, respectively. More than a third $(41.4 \%)$ of the respondents in the urban community had secondary education as against $(26.2 \%)$ of their rural contemporaries. Close to half $(47.4 \%)$ of the caregivers in the rural setting have no formal education. The main occupation of caregivers participating in the urban LGA $77.0 \%$ was petty trading while majority of rural $75.7 \%$ respondents were housewives; followed by civil servants $(15.3 \%)$ in the urban and petty traders (15.1) in the rural communities. Similarly, $16.7 \%$ versus $8.0 \%$ of the spouses of caregivers had tertiary education in the urban and rural communities respectively. The monthly income of urban respondents of $¥ 0$ to $\$ 210,000$ (median: $¥ 6,000$ ) was higher than that of rural respondents ( $\mathrm{N} 0$ to $\$ 70,000$; median: $\$ 3,500$ ) (Tables 1 and 2).

Two third $(73.5 \%)$ of the respondents in both settings were found to have utilized zinc plus ORS for diarrhoea management; up to $120(78.9 \%)$ of the caregivers in the urban community compared to over two third $102(68.0 \%)$ of those in the rural community had used zinc plus ORS (Tables 3 and 4). This difference was statistically significant between urban and rural caregivers $(\mathrm{P}<0.05)$.

At bivariate level, utilisation of zinc plus ORS was found to be significantly associated $(\mathrm{P}<0.05)$, with child's sex, respondent's sex, education, occupation, partner's education, knowledge, acceptability, severity of diarrhoea, partner's occupation and place of residence.

After adjusting for other covariates (child's sex, respondent's sex, occupation, partner's education, acceptability, and partners' occupation): knowledge, educational attainment, severity of diarrhoea and place of residence were found to remain independent predictors of utilisation of zinc plus ORS (Table 5), with caregivers having poor knowledge $98 \%$ less likely to use zinc plus ORS $(\mathrm{P}=0.00, \mathrm{AOR}=0.02,95 \% \mathrm{CI}=0.00$ 0.115 ), caregivers whose children had non severe diarrhoea are $80 \%$ less likely to use zinc plus $\mathrm{ORS}(\mathrm{P}=0.00, \mathrm{AOR}=0.20 .95 \%$ $\mathrm{CI}=0.09-0.47)$, caregivers with informal 
education are $75 \%$ less likely to use zinc plus ORS and caregivers in urban area are 1.5 times more likely to give zinc plus ORS $(\mathrm{P}=0.01, \mathrm{AOR}=1.53,95 \% \mathrm{CI}=1.48-4.54)$ for any episode of diarrhoea.

\section{Discussion}

Utilization of zinc plus ORS by care- givers was fair $(73.5 \%)$ in both settings; up to $120(78.9 \%)$ of the caregivers in the urban community compared to over two third $102(68.0 \%)$ of those in the rural community had used zinc plus ORS. This differ-

Table 1. Summary of socio-demographic characteristics of respondents.

\begin{tabular}{|c|c|c|c|c|c|}
\hline Variable & Total, n (\%) & Urban ( $\mathrm{n}=150) ; \mathrm{n}(\%)$ & Rural (n=152); n (\%) & $\chi^{2}$ & $P$ value \\
\hline $\begin{array}{l}\text { Age group (years) } \\
15-24 \\
25-34 \\
35-44 \\
45-49\end{array}$ & $\begin{array}{c}157(51.9) \\
110(36.4) \\
30(9.9) \\
5(1.8)\end{array}$ & $\begin{array}{c}69(46.4) \\
58(38.7) \\
19(12.7) \\
4(2.6)\end{array}$ & $\begin{array}{c}80(53.6) \\
42(27.6) \\
29(19.1) \\
1(0.7)\end{array}$ & 6.36 & $0.01^{*}$ \\
\hline $\begin{array}{l}\text { Caregiver's sex } \\
\text { Male } \\
\text { Female }\end{array}$ & $\begin{array}{c}5(1.7) \\
297(98.3)\end{array}$ & $\begin{array}{c}5(3.3) \\
145(96.7)\end{array}$ & $\begin{array}{c}0(0.0) \\
152(100)\end{array}$ & & $0.26 \dagger$ \\
\hline $\begin{array}{l}\text { Child's sex } \\
\text { Male } \\
\text { Female }\end{array}$ & $\begin{array}{l}159(52.6) \\
143(47.4)\end{array}$ & $\begin{array}{l}83(52.5) \\
67(47.2)\end{array}$ & $\begin{array}{l}76(47.5) \\
76(52.8)\end{array}$ & 0.86 & 0.35 \\
\hline $\begin{array}{l}\text { Tribe } \\
\text { Hausa/Fulani } \\
\text { Non-Hausa }\end{array}$ & $\begin{array}{c}294(97.4) \\
8(2.6)\end{array}$ & $\begin{array}{c}147(98.0) \\
3(2.0)\end{array}$ & $\begin{array}{c}147(96.7) \\
5(3.3)\end{array}$ & & $0.36 \dagger$ \\
\hline $\begin{array}{l}\text { Religion } \\
\text { Islam } \\
\text { Christianity }\end{array}$ & $\begin{array}{c}286(94.7) \\
16(5.3)\end{array}$ & $\begin{array}{c}143(95.3) \\
7(4.7)\end{array}$ & $\begin{array}{c}143(94.0) \\
9(6.0)\end{array}$ & 0.23 & 0.62 \\
\hline $\begin{array}{l}\text { Child's age } \\
\quad 0-11 \text { months } \\
12-59 \text { months }\end{array}$ & $\begin{array}{c}50(16.7) \\
252(83.3)\end{array}$ & $\begin{array}{c}30(20.0) \\
120(80.0)\end{array}$ & $\begin{array}{c}20(13.2) \\
132(86.8)\end{array}$ & 2.56 & 0.11 \\
\hline
\end{tabular}

$\dagger$ Fishers exact test. *Statistically significant.

Table 2. Other socio-demographic characteristics of respondents.

\begin{tabular}{|c|c|c|c|c|c|}
\hline Variable & Total, n (\%) & Urban (n=150); n (\%) & Rural (n=152); n (\%) & $x^{2}$ & P value \\
\hline $\begin{array}{l}\text { Marital Status } \\
\text { Single } \\
\text { Married }\end{array}$ & $\begin{array}{c}6(1.9) \\
296(98.1)\end{array}$ & $\begin{array}{c}3(2.0) \\
147(98.0)\end{array}$ & $\begin{array}{c}3(2.0) \\
149(98.0)\end{array}$ & & $1.00 \dagger$ \\
\hline $\begin{array}{l}\text { Education } \\
\text { None } \\
\text { Qur'anic } \\
\text { Primary } \\
\text { Secondary } \\
\text { Tertiary } \\
\end{array}$ & $\begin{array}{c}50(26.6) \\
55(18.2) \\
61(20.2) \\
121(41.4) \\
11(3.6)\end{array}$ & $\begin{array}{c}10(6.6) \\
24(15.8) \\
27(17.8) \\
85(55.9) \\
6(3.9)\end{array}$ & $\begin{array}{c}40(26.7) \\
31(20.7) \\
34(17.8) \\
40(26.7) \\
5(3.3)\end{array}$ & 35.9 & $0.01^{*}$ \\
\hline $\begin{array}{l}\text { Occupation } \\
\text { Civil servant } \\
\text { Business } \\
\text { Housewives }\end{array}$ & $\begin{array}{c}46(15.3) \\
134(77.0) \\
135(6.6)\end{array}$ & $\begin{array}{c}120(80.0) \\
23(15.3) \\
7(4.7)\end{array}$ & $\begin{array}{c}13(8.6) \\
24(15.1) \\
115(75.7)\end{array}$ & 46.9 & $<0.001^{*}$ \\
\hline $\begin{array}{l}\text { Income } \\
<\$ 2 / \text { day } \\
\geq \$ 2 / \text { day }\end{array}$ & $\begin{array}{c}246(81.5) \\
56(18.5)\end{array}$ & $\begin{array}{c}100(66.7) \\
50(33.3)\end{array}$ & $\begin{array}{c}146(96.0) \\
6(4.0)\end{array}$ & 10.9 & $<0.001^{*}$ \\
\hline $\begin{array}{l}\text { Caregiver type } \\
\text { Grandmother } \\
\text { Mother } \\
\text { Others }\end{array}$ & $\begin{array}{l}106(33.8) \\
162(55.0) \\
31(11.2)\end{array}$ & $\begin{array}{l}60(40.0) \\
70(46.7) \\
20(13.4)\end{array}$ & $\begin{array}{c}42(26.6) \\
96(63.2) \\
14(7.2)\end{array}$ & 8.29 & $0.02^{*}$ \\
\hline $\begin{array}{l}\text { Partner's Education } \\
\text { None } \\
\text { Quranic } \\
\text { Primary } \\
\text { Secondary } \\
\text { Tertiary } \\
\end{array}$ & $\begin{array}{c}19(6.3) \\
44(14.6) \\
31(10.3) \\
148(49.0) \\
60(19.9)\end{array}$ & $\begin{array}{c}6(8.7) \\
10(22.7) \\
12(12.7) \\
89(39.3) \\
35(16.7)\end{array}$ & $\begin{array}{c}13(3.9) \\
84(6.6) \\
19(7.9) \\
74(73.6) \\
10(8.0)\end{array}$ & 24.9 & $<0.001^{*}$ \\
\hline $\begin{array}{l}\text { Partner's occupation } \\
\text { Unemployed } \\
\text { Employed }\end{array}$ & $\begin{array}{c}42(15.9) \\
254(84.1)\end{array}$ & $\begin{array}{c}35(23.3) \\
115(76.7)\end{array}$ & $\begin{array}{c}13(8.6) \\
139(91.4)\end{array}$ & 12.33 & $<0.001^{*}$ \\
\hline $\begin{array}{l}\text { Number of living children } \\
\quad 1-4 \\
\geq 5\end{array}$ & $\begin{array}{c}301(99.7) \\
1(0.7)\end{array}$ & $\begin{array}{c}149(99.3) \\
1(0.7)\end{array}$ & $\begin{array}{c}152(100) \\
0(0.0)\end{array}$ & & $0.49 \dagger$ \\
\hline
\end{tabular}


ence was statistically significant between urban and rural caregivers $(\mathrm{P}=0.01)$. However, few caregivers in both rural and urban areas failed to complete the prescribed doses of zinc plus ORS. The result of the study showed a relatively higher rate of zinc plus ORS utilisation when compared with data from some studies in northern Nigeria; where a survey in northern Nigeria that focused on determining baseline data with respect to coverage, adherence and barriers to utilization of zinc and ORS observed that the coverage and utilization of zinc plus ORS for the treatment of diarrhoea were found to be $8.8 \%$ and $0.2 \%$ respectively. ${ }^{15}$ Similarly, a cross sectional survey in north western Nigeria found that ORS use was abysmally low at $8.6 \%{ }^{16}$
Only $32 \%$ of caregivers use zinc in the management of diarrhoea and adherence to 10 day zinc supplementation was encouraging at $75.5 \%{ }^{16}$ NDHS 2013 also reported a very low utilisation of zinc (3.1\%) and ORS $(39.4 \%)$ for the northwest region. ${ }^{2}$ However, the study result was comparable to MICS 2016/2017 report where zinc and ORS dosing compliance rate for children

Table 3. Utilisation of zinc plus ORS.

\begin{tabular}{lccccc} 
Utilisation & Urban n(\%) & Rural n(\%) & $\chi^{2}$ & & P-value \\
Yes & $120(78.9)$ & $102(68.0)$ & $222(73.5)$ & & \\
No & $30(21.1)$ & $50(32.0)$ & $80(26.5)$ & 5.80 & $0.01 *$ \\
\hline
\end{tabular}

*Statistically significant difference.

Table 4. Factors associated with utilisation of zinc plus ORS.

\begin{tabular}{|c|c|c|c|c|c|}
\hline Variable & Yes, n(\%) & $\begin{array}{l}\text { Utilisation } \\
\text { No, n(\%) }\end{array}$ & Total, n(\%) & $x^{2}$ & P value \\
\hline $\begin{array}{l}\text { Age } \\
\quad \begin{array}{l}<30 \\
>30\end{array}\end{array}$ & $\begin{array}{c}164(71.6) \\
58(79.5)\end{array}$ & $\begin{array}{l}65(28.4) \\
15(20.5)\end{array}$ & $\begin{array}{c}229(75.8) \\
73(24.2)\end{array}$ & 1.75 & 0.08 \\
\hline $\begin{array}{l}\text { Child's sex } \\
\text { Male } \\
\text { Female }\end{array}$ & $\begin{array}{c}127(79.9) \\
95(66.4)\end{array}$ & $\begin{array}{l}32(20.1) \\
48(33.6)\end{array}$ & $\begin{array}{l}159(52.6) \\
143(47.4)\end{array}$ & 6.99 & $<0.01^{*}$ \\
\hline $\begin{array}{l}\text { Respondent's Sex } \\
\text { Male } \\
\text { Female }\end{array}$ & $\begin{array}{c}2(40.0) \\
197(90.8)\end{array}$ & $\begin{array}{l}3(60.0) \\
20(9.2)\end{array}$ & $\begin{array}{c}5(2.3) \\
217(97.7)\end{array}$ & & $<0.01 \dagger$ \\
\hline $\begin{array}{l}\text { Religion } \\
\text { Islam } \\
\text { Christianity } \\
\end{array}$ & $\begin{array}{c}211(73.8) \\
11(68.8)\end{array}$ & $\begin{array}{c}75(26.2) \\
5(31.2)\end{array}$ & $\begin{array}{c}286(94.7) \\
16(5.3)\end{array}$ & 0.19 & 0.66 \\
\hline $\begin{array}{l}\text { Tribe } \\
\text { Hausa/Fulani } \\
\text { Non Hausa }\end{array}$ & $\begin{array}{c}216(75.5) \\
9(56.3)\end{array}$ & $\begin{array}{l}70(24.5) \\
7(43.7)\end{array}$ & $\begin{array}{c}286(94.7) \\
16(5.3)\end{array}$ & 2.96 & 0.08 \\
\hline $\begin{array}{l}\text { Marital Status } \\
\text { Single } \\
\text { Ever Married }\end{array}$ & $\begin{array}{c}6(46.2) \\
214(74.0)\end{array}$ & $\begin{array}{c}7(53.8) \\
75(26.0)\end{array}$ & $\begin{array}{c}6(3.3) \\
296(96.3)\end{array}$ & 2.73 & 0.06 \\
\hline $\begin{array}{l}\text { Education } \\
\text { Formal } \\
\text { Informal }\end{array}$ & $\begin{array}{c}20(40.0) \\
182(72.2)\end{array}$ & $\begin{array}{l}30(60.0) \\
70(27.8)\end{array}$ & $\begin{array}{c}50(16.6) \\
252(83.4)\end{array}$ & 19.6 & $<0.01 *$ \\
\hline $\begin{array}{l}\text { Occupation } \\
\text { Employed } \\
\text { Unemployed }\end{array}$ & $\begin{array}{l}161(68.5) \\
61(91.0)\end{array}$ & $\begin{array}{c}74(31.5) \\
6(9.0)\end{array}$ & $\begin{array}{c}235(77.7) \\
67(22.2)\end{array}$ & 13.6 & $<0.01^{*}$ \\
\hline $\begin{array}{l}\text { Partner's Education } \\
\text { Formal } \\
\text { Informal }\end{array}$ & $\begin{array}{c}18(94.7) \\
200(72.1)\end{array}$ & $\begin{array}{c}1(5.3) \\
77(27.9)\end{array}$ & $\begin{array}{c}16(5.4) \\
280(94.6)\end{array}$ & & $0.03 \dagger$ \\
\hline $\begin{array}{l}\text { Partner's Occupation } \\
\text { Employed } \\
\text { Unemployed } \\
\end{array}$ & $\begin{array}{c}23(47.9) \\
195(78.3)\end{array}$ & $\begin{array}{l}23(52.1) \\
55(21.7)\end{array}$ & $\begin{array}{c}48(16.2) \\
248(83.8)\end{array}$ & 19.2 & $<0.001^{*}$ \\
\hline $\begin{array}{l}\text { Knowledge } \\
\text { Fair/Good } \\
\text { Poor }\end{array}$ & $\begin{array}{c}215(71.1) \\
5(11.7)\end{array}$ & $\begin{array}{l}65(28.9) \\
39(88.6)\end{array}$ & $\begin{array}{c}280(92.7) \\
44(7.2)\end{array}$ & 21.2 & $<0.001^{*}$ \\
\hline $\begin{array}{l}\text { Acceptability } \\
\text { Poor } \\
\text { Good }\end{array}$ & $\begin{array}{c}42(100) \\
0(0.0)\end{array}$ & $\begin{array}{c}0(0.0) \\
180(100)\end{array}$ & $\begin{array}{c}42(18.9) \\
180(81.1)\end{array}$ & & $<0.01 \dagger$ \\
\hline $\begin{array}{l}\text { Severity } \\
\quad<4 \\
\quad \geq 4\end{array}$ & $\begin{array}{c}30(39.0) \\
190(84.4)\end{array}$ & $\begin{array}{l}47(61.0) \\
35(15.6)\end{array}$ & $\begin{array}{l}77(25.50) \\
225(74.5)\end{array}$ & 60.0 & $<0.001^{*}$ \\
\hline $\begin{array}{c}\text { Residence } \\
\text { Rural } \\
\text { Urban }\end{array}$ & $\begin{array}{l}102(68.0) \\
120(80.0)\end{array}$ & $\begin{array}{l}50(22.0) \\
30(20.0)\end{array}$ & $\begin{array}{l}152(50.3) \\
150(49.7)\end{array}$ & 5.80 & $<0.001^{*}$ \\
\hline
\end{tabular}


Table 5. Predictors of utilisation of zinc plus ORS.

\begin{tabular}{|c|c|c|c|c|}
\hline Variable & Utilisation n(\%) & Crude OR & Adjusted OR (95\% CI) & $P$ value \\
\hline $\begin{array}{l}\text { Knowledge } \\
\text { Poor } \\
\text { Good/Fair }\end{array}$ & $\begin{array}{c}44(14.6) \\
258(85.4)\end{array}$ & $\begin{array}{c}1 \\
3.78\end{array}$ & $0.02(0.00-0.12)$ & $0.00^{*}$ \\
\hline $\begin{array}{l}\text { Severity } \\
\quad<4 \\
\geq 4 \\
\end{array}$ & $\begin{array}{c}230(76.2) \\
72(23.8)\end{array}$ & $\begin{array}{c}1 \\
1.58\end{array}$ & $0.20(0.09-0.47)$ & $0.00^{*}$ \\
\hline $\begin{array}{l}\text { Acceptability } \\
\text { Poor } \\
\text { Good }\end{array}$ & $\begin{array}{l}42(18.9) \\
180(81.1)\end{array}$ & $\begin{array}{c}1 \\
1.24\end{array}$ & $1.17(0.08-1.93)$ & 0.23 \\
\hline $\begin{array}{c}\text { Residence } \\
\text { Rural } \\
\text { Urban } \\
\end{array}$ & $\begin{array}{l}120(54) \\
102(46)\end{array}$ & $\begin{array}{c}1 \\
2.23\end{array}$ & $1.53(1.48-4.54)$ & $0.01^{*}$ \\
\hline $\begin{array}{l}\text { Child Sex } \\
\text { Male } \\
\text { Female }\end{array}$ & $\begin{array}{l}159(52.6) \\
143(47.4)\end{array}$ & $\begin{array}{c}1 \\
6.33\end{array}$ & $4.90(0.33-30.17)$ & 0.09 \\
\hline $\begin{array}{l}\text { Caregivers Sex } \\
\text { Male } \\
\text { Female } \\
\end{array}$ & $\begin{array}{c}5(1.7) \\
297(98.3)\end{array}$ & $\begin{array}{c}1 \\
3.4\end{array}$ & $2.94(0.66-13.25)$ & 0.16 \\
\hline $\begin{array}{l}\text { Education } \\
\text { Informal } \\
\text { Formal }\end{array}$ & $\begin{array}{c}50(16.6) \\
252(83.4)\end{array}$ & $\begin{array}{c}1 \\
0.47\end{array}$ & $0.25(0.09-0.69)$ & $0.01^{*}$ \\
\hline $\begin{array}{l}\text { Occupation } \\
\text { Unemployed } \\
\text { Employed }\end{array}$ & $\begin{array}{l}67(22.2) \\
235(77.8)\end{array}$ & $\begin{array}{c}1 \\
2.96\end{array}$ & $2.01(0.67-12.81)$ & 0.15 \\
\hline $\begin{array}{l}\text { Partner's Education } \\
\text { Informal } \\
\text { Formal }\end{array}$ & $\begin{array}{c}280(94.6) \\
16(5.4)\end{array}$ & $\begin{array}{c}1 \\
0.31\end{array}$ & $0.35(0.10-1.18)$ & 0.91 \\
\hline $\begin{array}{l}\text { Partner's Occupation } \\
\text { Unemployed } \\
\text { Employed }\end{array}$ & $\begin{array}{r}248(83.8) \\
48(16.2)\end{array}$ & $\begin{array}{c}1 \\
0.15\end{array}$ & $0.18(0.02-1.68)$ & 0.18 \\
\hline
\end{tabular}

*Statistically significant.

with diarrhoea was found to be $36.7 \%$ and $43.8 \%$ respectively for the north-western states of Nigeria. ${ }^{17}$ The high proportion of zinc plus ORS users in this study group is likely because the State government $(\mathrm{MOH}$ and its parastatals) and development partners have been collaborating in improving the home management of diarrhoea and increasing the use of zinc plus ORS and the widespread availability of co-parked zinc plus ORS. Strategies used includes training/retraining of healthcare workers on use of zinc plus ORS, provision of zinc plus ORS to all patent medicine vendors, mass media campaigns and engagement of community key influencers in all the political wards in the state on childhood diarrhoea and other maternal and child health interventions.

Utilisation of zinc plus ORS was found to be significantly associated $(\mathrm{P}<0.05)$ with child's sex, caregiver's sex, education, occupation, partner's education, knowledge about zinc plus ORS, acceptability of zinc plus ORS, severity of diarrhoea, partner's occupation and place of residence.

After adjusting for other covariates: knowledge, education, place of residence and severity of diarrhoea remain significant predictors of utilisation of zinc plus ORS, with caregivers having poor knowledge 98\% less likely to use zinc plus ORS, caregivers whose children had non severe diarrhoea are $80 \%$ less likely to use zinc plus ORS, caregivers with informal education are also $75 \%$ less likely to use zinc plus ORS and caregivers in urban areas are 1.5 times more likely to give zinc plus ORS for any episode of diarrhoea. A study in Kano found that availability of health centres and ORS were the main factors associated with utilisation, ${ }^{18}$ while studies from some northern states and Edo (Nigeria) revealed availability of zinc plus ORS, knowledge, preference for herbal medicines, age, marital status, educational status and social class of mothers were significant determinants of utilisation. ${ }^{19,20}$ A study on health utilization and attitude survey conducted in rural Gambia to identify possible predictors of diarrhoea and the decision to seek treatment at a health facility reported that signs of dehydration (dry mouth, lethargy), diarrhoea with fever and vomiting were found to be significant predictors of seeking treatment at a health facility. ${ }^{21}$ Similarly, surveys in selected districts of Benin Republic, Nepal, Iran and India among caregivers cited that availability, compliance cards, caregivers' previous experience, SMS reminders, dehydration, severe diarrhoea, vomiting, counselling/advise by health workers and belief about effectiveness of zinc plus ORS was found to be associated with good utilization of zinc and ORS among the surveyed participants. ${ }^{22-25}$

\section{Conclusions}

Utilisation of zinc plus ORS was found to be fair in both rural and urban areas of Kano and continued efforts to reach caregivers using a variety of channels are needed to further improve caregiver's knowledge and utilization of zinc plus ORS and alter incorrect diarrhoea treatment practices. These efforts should be rigorously evaluated and accompanied by health promotion activities with all stakeholders to ensure adequate supply and availability of zinc plus ORS products in all facilities.

\section{References}

1. International Vaccine Access Center 
(IVAC), Johns Hopkins Bloomberg School of Public Health. Pneumonia and Diarrhea Progress Report 2015: Sustainable Progress in the Post-2015 Era. Retrieved from www.jhsph.

2. National Population Commission and ICF Macro. Nigeria Demographic and Health Survey, Abuja, Nigeria, and Rockville, Maryland, USA: NPC and ICF International,2013;566. www.population.gov.ng. accessed 2/12/2016)

3. Wardlaw T, Salama P, Brocklehurst C, et al. Diarrhoea: why children are still dying and what can be done. Lancet 2010;375:870-2.

4. Barl R. Effect of zinc supplimentation on course of acute diarrhoea, New Delhi. J Health Pop Nutr 2009;9:33846.

5. Mark Y, Calthy W, David MR, Diaa H. World Health Organisation/United nations children's fund joint statement. Am J Trop Med Hyg 2012;87:6-10.

6. Lopez A, Mathers C. Global burden of disease and risk factors. Lancet 2016:1747-57.

7. Walker-Smith JA, Murch SH. Diarrhoea in Childhood. Medicine (Baltimore) 2003;31:41-4.

8. Whyte LA, Jenkins HR. Pathophysiology of diarrhoea. Paediatr Child Health 2012;22;43-7.

9. Kung'u K, Owolabi O, Essien G, et al. Promotion of Zinc Tablets with ORS through Child Health Weeks Improves Caregiver Knowledge, Attitudes, and Practice on Treatment of Diarrhoea in Nigeria. J Health Pop Nutr 2015;23:133.

10. Hennekens CH. Epidemiology in Medicine. Boston: Little, Brown; 1987.
11. Mbiti EN, Kungu J, Kabaka S, Lengewa C. Barriers and facilitating factors for uptake of zinc and ORS in Kenya; a case of Kitui County. J Health Pop Nutr 2006;3:23.

12. Chattopadhyay K. Awareness of Oral rehydration salt (ORS) among mothers of under-five children in Kamala Village, West Bengal, India: EuroPubhealth 2011;12.

13. Nielsen M, Hoogvorst A, Konradsen F, Mudasser M. Causes of childhood diarrhea As perceived By mothers in the Punjab, Pakistan. 2000.

14. Otieno GA, Bigogo GM, Nyawanda $\mathrm{BO}$, et al. Caretakers perception towards using Zinc to treat childhood diarrhoea in rural western Kenya. J Heal Popul Nutr 2013;31:321-9.

15. Falana AO, Adegoke O, Sambo A, Kungu J. Caregiver's knowledge, attitudes and practices on the utilization of Zinc and LO-ORS for diarrhoeal treatment in Northern Nigeria. Micronutr Iniative 2015;1513

16. Ogunrinde OG, Raji T, Owolabi OA. Knowledge, attitude and practice of home management of childhood diarrhoea among caregivers of under-5 children with diarrhoeal disease in Northwestern Nigeria. J Trop Paedtr 2012;58:143-6.

17. Nigeria; Multiple Indicator Cluster Survey. Survey Finding Report August 2017.

18. Umar LB, Umar I. Comparative studies of knowledge and perception of parents on home managements of diarrheal diseases among under five children between two communities of Kano State, Nigeria. Int J Pharm Sci Invent
2015;4:23-31.

19. Tobin EA, Isah EC, Asogun DA. Caregiver's knowledge about childhood diarrhoea. Nigeria Int J Community Res 2011;23:93-9.

20. Oladipo AR, Falana A, Adegoke O, Sambo A. Caregiver's Knowledge, attitudes and practices on the utilization of zinc and lo-ORS for diarrhea treatment in northern Nigeria. Eur J Nutr Food Saf 2015;5:846-7.

21. Saha D, Akinsola A, Sharples K, et al. Health care utilization and attitudes survey: Understanding diarrheal disease in rural Gambia. Am J Trop Med Hyg 2013;89:13-20.

22. Amir AG, Ahmad T, Negin MA. Knowledge of mothers in management of diarrheoa in under-five children, in Kashan, Iran - nursing and midwifery studies - Kashan University of medical sciences 2013;158-62.

23. Eashin G, Aniket C, Rakesh K, et al. Acute diarrhoeal disease management by caregivers. J Evid Based Med Heal Care 2015;2:5575-84.

24. Omuemu VO, Ofuani IJ, Kubeyinje IC. Knowledge and use of zinc zupplementation in the management of childhood diarrhoea among health care workers in public primary health facilities in Benin-City, Nigeria. Glob J Health Sci 2012;4:68-76.

25. Lamberti LM, Fischer Walker CL, Taneja S, et al. The Influence of Episode Severity on Caregiver Recall, Care-seeking, and Treatment of Diarrhea Among Children 2-59 Months of Age in Bihar, Gujarat. Am J Trop Med Hyg 2015;14:250-6. 